that was used in computing the coefficient; we do not know how the electrons in the observation tube were affected by the temperature variation of the medium surrounding it. It can, however, be safely assumed that on account of the high initial value of the electron temperature, its percentage variation was much less than the percentage variation of molecular temperature. The temperature coefficient computed by taking the molecular temperature is therefore necessarily smaller than the true coefficient. (It is to be remembered that J. J. Thomson's expression for $\alpha$ has not been tested for the pressures such as are ordinarily encountered in discharge tubes, and it is doubtful if the formula is strictly applicable to such cases, particularly because of the uncertainty regarding the energy free path $\lambda$. Nevertheless, the formula can be assumed to give, at least qualitatively, the nature of the variation of $\alpha$ with temperature, pressure and concentration).

Wireless Laboratory,

University College of Science,

92 Upper Cireular Road,

Calcutta. Sept. 14.

'Mitra, S. K., Science and Culture (Calcutta), 9, 49 (1943) ; 10, 133 (1944).

${ }^{2}$ Mitra, S. K., Nature, 154, 212 (1944).

3 Rayleigh, Lord, Proc. Roy. Soc., A, 151, 567 (1935).

- Rayleigh, Lord, Proc. Roy. Soc., A, 176, 1 (1940); see data in p. 5 ; see also ref. 3, p. 576 .

$\checkmark$ See ref. 4, p. 10.

- See ref. 3, p. 13

7 Thomson, J. J., Phil. Mag., 47, 337 (1924),

\section{Borax as a Standard Buffer Solution}

UsERs of glass electrodes frequently require for purposes of standardization an easily prepared buffer solution in the region of $p \mathbf{H ~ 9}$, and use is generally made of an $M / 20$ solution of A.R. borax, which according to tables ${ }^{1}$ has a value of $9 \cdot 23$ at $20^{\circ} \mathrm{C}$.

In the investigation of small errors in glass electrodes, it was found that the $M / 20$ borax solution gave results which were invariably lower than the accepted values by about $p \mathrm{H} 0.05$, and it was thought that these irregular results should be investigated as other workers might find similar diffculties in correlating data.

Samples of A.R. grade borax, made by reputable manufacturers, were first used, but it was found that when the solutions were prepared under the same conditions the results were uniformly low, indicating that the irregular results were not apparentiy due to methods of preparation of the material.

It has been stated ${ }^{2}$ that $M / 20$ borax solution has a $p H$ value of $9 \cdot 18$ at $25^{\circ} \mathrm{C}$. when the salt is treated so that it has the correct state of hydration, and as a check on this point a sample of borax was dehydrated to avoid errors of hydration. The $p H$ value of an $M / 20$ solution of the salt so prepared was $9 \cdot 13_{2}\left(9 \cdot 17_{2}\right.$ at $20^{\circ} \mathrm{C}$.), which is still below the correct value.

A second sample was now prepared by dissolving the salt in boiling water to which sodium hydroxide was added to neutralize any possible traces of free boric acid. The salt was recrystallized from this solution and again recrystallized twice from distilled water. The product of each crystallization was filtered under vacuum and washed with distilled water. The final product was dried between filter paper in the air. A solution $M / 20$ in strength was used for the test.
All the $M / 20$ solutions were prepared from distilled water boiled in a 'Pyrex' flask and cooled with a soda-lime tube absorber for carbon dioxide. The $p H$ measurements were made with hydrogen and calomel electrodes kept at constant temperature for 24 hours previous to the tests. Under these conditions the calomel cell has been found to give potentials in agreement ith those given by Michaelis ${ }^{3}$, and as a check an $M / 20$ potassium hydrogen phthalate solution ( $p \mathrm{H} 3.97$ ) was tested. This showed the calomel cell had a potential correct to within 0.2 millivolt of Michaelis' values, and all readings of the various tests on the borax solutions were steady to $0 \cdot 2$ millivolt.

\begin{tabular}{|c|c|c|c|c|}
\hline $\begin{array}{l}\text { Hydrogen } \\
\text { electrode } \\
\text { o C. }\end{array}$ & $\begin{array}{l}\text { Calomel } \\
\text { electrode } \\
{ }^{\circ} \text { C. }\end{array}$ & $\begin{array}{l}\text { E.M.F. } \\
\text { mV. }\end{array}$ & $p \mathrm{H}$ & $\begin{array}{c}p \mathrm{H} \text { reduced } \\
\text { to } 20^{\circ} \mathrm{C} \text {. }\end{array}$ \\
\hline $\begin{array}{l}20 \cdot 2 \\
20 \cdot 8 \\
21 \cdot 0\end{array}$ & $\begin{array}{l}20 \cdot 5 \\
21 \cdot 2 \\
21 \cdot 2\end{array}$ & $\begin{array}{l}782 \cdot 6 \\
782 \cdot 6 \\
782 \cdot 8\end{array}$ & $\begin{array}{l}9 \cdot 18_{8} \\
9 \cdot 17_{0} \\
9 \cdot 17_{7}\end{array}$ & $\begin{array}{l}9 \cdot 18_{0} \\
9 \cdot 17_{6} \\
9 \cdot 17_{\mathrm{B}}\end{array}$ \\
\hline
\end{tabular}

From a long series of tests extending over several years, it has been found that the temperature coelficient of the $M / 20$ solution of borax as given by Walbum ${ }^{4}$ is quite correct even though the absolute $p \mathbf{H}$ value differs from his figures somewhat.

The $p \mathrm{H}$ values at $20^{\circ} \mathrm{C}$. are computed on the basis of Walbum's figures, and rounding them off to the nearest $p \mathrm{H} 0.0 \mathrm{~J}$, which is the limit of accuracy of ordinary $p H$ measurements, it would seem that a value of $9 \cdot 18$ for an $M / 20$ solution of $\mathrm{Na}_{2} \mathrm{~B}_{4} \mathrm{O}_{2}$. $10 \mathrm{H}_{2} \mathrm{O}$ made up with carbon dioxide - free distilled water represents the more correct figure than 9.23 usually given.

It is dificult to offer any explanation of the discrepancy, since the original figures given by Walbum were presumably made with a hydrogen electrode. The value of 9.18 at $25^{\circ} \mathrm{C}$. quoted by Hitchcock and Taylor ${ }^{1}$ may have been based on a value of $p \mathbf{H} 4.00_{5}$ for $M / 20$ potassium hydrogen phthalate. Reducing their figure to the more usual value of $3 \cdot 97$, this gives $9 \cdot 15$, which is still $p \mathrm{H} 0.02$ above the value usually found, a small but very definite discrepancy. It would be interesting to learn other workers; opinions on this point.

Cambridge Instrument Co., Ltd. 47 Sydney Road,

London, N.I0.

Sept. 22.

I "Hydrogen Ions". By H. T. S. Britton.

${ }^{2}$ Hitchcock, D. I., and Taylor, A. C., J. Amer. Chem. Soc., 1812 1937).

"Michaelis, L., "Die Wasserstoffionenkorizentration".

"Clark, W. M., "The Determination of Hydrogen Ions".

\section{Identification of the Montmorillonite Group of Minerals by X-Rays}

ThIS group of elay minerals (referred to hereafter for brevity simply as "montmorillonite"), which is often found in soil clays, fuller's earth and bentonite, is characterized by the variation of the position of the basal reflexion, on an $\mathrm{X}$-ray powder or aggregate diagram, from about 10 to about $18 \mathrm{~A}$., according to the state of hydration ${ }^{1}$. The minerals of the group are notoriously difficult to identify positively from a single $\mathrm{X}$-ray diagram because $(a)$ the line at $14 \mathrm{~A}$., which is given by montmorillonite in a normal state of hydration, is liable to be confused with a basal 